\title{
UPAYA MENINGKATKAN HASIL BELAJAR MATEMATIKA MELALUI METODE PEMBELAJARAN CONTEXTUAL TEACHING AND LEARNING (Studi di Kelas XI IPA SMAN 1 Pandeglang)

\author{
IMPROVING MATHEMATICS' LEARNING ACHIEVEMENT THROUGH \\ CONTEXTUAL TEACHING AND LEARNING METHOD \\ (Study at Eleventh Grade IPA of SMAN 1 Pandeglang)
}

\author{
BUDI HARTONO \\ SMA Negeri 1 Pandeglang \\ Jalan Raya Serang KM. 3 Cigadung Pandeglang \\ Ponsel: 081218141542/08128745034
}

\begin{abstract}
Abstrak
Penelitian ini bertujuan untuk mengetahui peningkatan hasil belajar Matematika melalui penerapan metode pembelajaran Contextual Teaching and Learning pada siswa kelas XI IPA SMAN 1 Pandeglang. Jenis penelitian ini merupakan penelitian tindakan kelas. Pelaksanaan penelitian tindakan kelas ini terdiri atas dua siklus. Hasil evaluasi pada prasiklus menunjukkan persentase siswa yang mencapai nilai lebih dari $\geq 7,5$ hanya 51 siswa dengan ketuntasan 29,41\%. Dari hasil evaluasi pelajaran Matematika pada siklus satu, menunjukkan persentase siswa yang mencapai nilai $\geq 75$ mencapai $52,94 \%$, atau 92 siswa. Dari hasil evaluasi pelajaran Matematika di siklus dua, jumlah siswa yang telah mencapai $\geq 75$ berjumlah 154 siswa atau $88,23 \%$. Hasil ini menunjukkan ketuntasan secara klasikal sudah berhasil karena batas ketuntasan yaitu $\geq 85 \%$.
\end{abstract}

Kata kunci: hasil belajar Matematika, Contextual Teaching and Learning

\begin{abstract}
This study aims to know the improvement of mathematics' learning achievement through Contextual Teaching and Learning methods at eleventh grade IPA of SMAN 1 Pandeglang. This research is classroom action research. The implementation of this classroom action research consisted of two cycles. The result of the evaluation at precycle shows the students who achieved values more than $\geq 7.5$ only 51 , or $29.41 \%$. The result of the evaluation at cycle one shows the students who achieved $\geq 75$ scores reached $52.94 \%$, or 92 students. From the result of the evaluation at cycle two, the number of students who reached $\geq 75$ are 154 students, or $88.23 \%$. The result shows classical improvement has been successful achieved due to its mastery limit for about $\geq 85 \%$.
\end{abstract}

Keywords: Mathematics' learning achievement, Contextual Teaching and Learning

\section{PENDAHULUAN}

Pemilihan dan penggunaan tujuan kompetensi sangat diperlukan

metode yang tepat sesuai dengan bagi guru karena metode adalah cara 
yang digunakan guru untuk diajarkan dengan situai dunia nyata mengadakan hubungan dengan siswa pada saat pembelajaran. Untuk itu, guru sebagai pengarah dan pembimbing tidak hanya pandai dalam memilih metode pembelajaran, namun usaha guru untuk mengoptimalkan komponen pembelajaran juga diperlukan dalam rangka meningkatkan hasil belajar siswa.

Pengembangan metode yang tidak sesuai dengan tujuan pembelajaran akan menjadi kendala untuk mencapai tujuan yang telah dirumuskan. Sebagai seorang guru matematika misalnya, tentu memiliki harapan agar siswanya mendapatkan hasil belajar yang baik. Namun, fakta di lapangan menunjukkan hasil belajar siswa pada mata pelajaran matematika masih rendah. Permasalahan yang jamak ditemukan yaitu siswa malas latihan soal matematika sehingga dasar pemahaman konsep matematikanya mudah lupa.

Kunci belajar matematika adalah pemahaman konsep dan latihan soal. Permasalah besar yang dihadapi siswa adalah mereka belum terbiasa menghubungkan antara apa yang mereka pelajari dan bagaimana pengetahuan itu akan digunakan. Pada pelajaran matematika dibutuhkan proses untuk memahami materi yang siswa. Dengan demikian, belajar matematika diperlukan bimbingan yang mendorong siswa untuk membuat hubungan antara pengetahuan yang dimilikinya dengan penerapan kehidupan nyata mereka.

Kemudian, pembelajaran Contextual Teaching and Learning merupakan model pembelajaran yang dapat membantu guru mengaitkan materi yang diajarkan dengan situasi dunia nyata siswa, dan mendorong siswa menghubungkan pengetahuan yang dimilikinya dengan kehidupan nyata. Model CTL dapat mendorong guru untuk menciptakan proses belajar mengajar yang bisa menumbuhkan ketertarikan siswa dalam belajar matematika khususnya dan umumnya belajar mata pelajaran lain. Model CTL ini berisikan metode pembelajaran yang bervariatif, tepat, dan efektif dalam penyampaian materi. Berdasarkan paparan tersebut, diharapkan CTL mampu mengembangkan pembelajaran yang efektif pada proses pembelajaran Matematika di kelas XI IPA SMAN 1 Pandeglang.

\section{KAJIAN TEORETIK}

Belajar adalah suatu proses usaha yang dilakukan seseorang untuk 
memperoleh suatu perubahan tingkah laku yang baru secara keseluruhan, sebagai hasil pengalamannya sendiri dalam interaksi dengan lingkungannya, baik dalam aspek kognitif, psikomotorik, maupun sikap (Slameto, 2010: 2). Ketiga aspek tersebut merupakan satu kesatuan yang tidak terpisahkan. Oleh karena itu dalam kegiatan pembelajaran harus berjalan efektif agar mampu memengaruhi hasil belajar siswa. Hasil belajar adalah bukti keberhasilan dari seseorang setelah memperoleh pengalaman belajar atau mempelajari sesuatu.

Berdasarkan pengertian di atas, dapat disimpulkan bahwa hasil belajar merupakan hasil yang telah dicapai oleh siswa dalam kegiatan belajar yang ditunjukkan dengan nilai tes atau angka dari hasil evaluasi yang diberikan oleh guru. Hasil belajar adalah seluruh kecakapan atau kemampuan seseorang, baik kognitif, afektif, maupun psikomotor yang diperoleh melalui aktivitas belajar yang dapat diukur menggunakan tes. Hasil belajar juga digunakan untuk memenuhi kebutuhan pengajaran misalnya keputusan yang menyangkut ketepatan kurikulum, metode pengajaran, metode bimbingan yang diberikan guru maupun sekolah dalam proses pembelajarannya.
Untuk mengatasi berbagai problematika dalam pelaksanaan pembelajaran, tentu diperlukan metode mengajar yang dipandang mampu mengatasi kesulitan guru melaksanakan tugas mengajar dan juga kesulitan belajar peserta didik. Metode adalah salah satu alat untuk mencapai tujuan. Sedangkan, pembelajaran adalah suatu kegiatan yang dilakukan oleh guru sedemikian rupa sehingga tingkah laku siswa berubah ke arah yang lebih baik.

Lebih lanjut, pembelajaran Contextual Teaching and Learning merupakan model pembelajaran yang dapat mengaitkan antara materi pelajaran dengan situasi dunia nyata yang berkembang dan terjadi dilingkungan sekitar sehingga siswa mampu menghubungkan dan menerapkan kompetensi hasil belajar dengan kehidupan sehari-hari mereka. Selain itu, CTL juga dapat membantu guru mengaitkan antara materi yang diajarkanya dengan situasi dunia nyata siswa dan mendorong siswa membuat hubungan antara pengetahuan yang dimilikinya dengan penerapan dalam kehidupan sehari-hari.

Menurut Sanjaya (2013: 256), dalam proses pembelajaran Contextual Teaching and Learning terdapat lima karakteristik penting. (1) 
Activating knowledge, artinya apa yang akan dipelajari tidak terlepas dari pengetahuan yang sudah dipelajari. (2) Understanding knowledge, artinya pengetahuan yang diperoleh bukan untuk dihafal tapi untuk dipahami dan diyakini. (3) Acquiring knowledge, yaitu memperoleh pengetahuan baru dengan cara deduktif artinya pembelajaran dimulai dengan mempelajari secara sederhana kemudian memperhatikan detailnya. (4) Applying knowledge, artinya pengetahuan dan pengalaman yangdiperoleh harus dapat diaplikasikan dalam kehidupan pesera didik. (5) Reflecting knowledge artinya melakukan refleksi terhadap strategi pengembangan pengetahuan sebagai umpan balik untuk proses perbaikan dan penyempurnaan strategi.

Menurut Sani (2013: 93), pembelajaran berbasis Contextual Teaching and Learning disusun untuk memungkinkan terjadinya lima bentuk belajar. (1) Relating (mengaitkan) belajar dikaitkan dengan konteks pengalaman kehidupannyata. Konteks merupakan kerangka kerja yang dirancang guru untuk membantu peserta didik agar yang dipelajari bermakna.

(2) Experiencing (mengalami) belajar adalah kegiatan "mengalami", peserta didik berproses secara aktif dengan hal yang dipelajari dan berupaya melakukan ekspolasi terhadap hal yang dikaji, berusaha menemukan hal baru dari apa yang dipelajarinya. (3) Applying (menerapkan) belajar menekankan pada proses mendemontrasikan pengetahuan yang dimiliki dalam konteks dan pemanfaatannya. (4) Cooperating (bekerjasama) belajar merupakan proses kolaboratif dan kooperatif melalui belajar berkelompok, komunikasi interpersonal atau hubungan inter subjektif. (5) Transferring (mentransfer) belajar menekankan pada terwujudnya kemampuan memanfaatkan pengetahuan dalam situasi atau konteks baru.

\section{METODE PENELITIAN}

Metode dalam penelitian ini yaitu penelitian tindakan. Subjek penelitian merupakan seluruh siswa di kelas $\mathrm{XI}$ IPA SMA Negeri 1 Pandeglang. Penelitiannya sendiri dilaksanakan sebanyak dua siklus dengan prosedur penelitian mencakup tahap perencaan, tindakan, observasi, dan refleksi.

\section{HASIL DAN PEMBAHASAN}

Hasil penelitian pada siklus satu menunjukkan persentase siswa yang mencapai nilai $\geq 75$ baru mencapai 
$52,94 \%$, atau sebanyak 93 siswa. Hal ini terjadi karena siswa kurang memahami dan mengerti konsep pelajaran matematika dalam menyelesaikan pembelajaran matematika. Dari hambatan-hambatan yang terjadi pada siklus satu maka pada siklus dua peneliti merencanakan strategi perbaikan-perbaikan.

Hasil pada siklus dua menunjukkan jumlah siswa yang telah mencapai $\geq 75$ adalah 154 siswa atau $88,23 \%$. Secara klasikal, hal ini menunjukkan ketuntasan karena batas ketuntasan $\geq 85 \%$.

Peningkatan hasil belajar siswa terlihat meningkat dari sebelum tindakan, Siklus 1, dan Siklus 2. Dari jumlah siswa yang telah mencapai $\geq$ 75 sebelum tindakan (SO) yaitu 51 siswa $(29,41 \%)$, Siklus 1 yaitu 93 siswa (52,94\%), Siklus 2 yaitu 134 siswa (88,23\%). Pada Siklus 2, jumlah siswa yang belum tuntas sebanyak 21 siswa. Adapun upaya terhadap siswa yang belum tuntas tersebut adalah memberikan bimbingan, kemudian diberikan tindakan, evaluasi perbaikan diluar jam pelajaran atau diluar kegiatan belajar mengajar.

\section{SIMPULAN}

Sebagai akhir dari pembahasan hasil penelitian ini, penulis mencoba untuk menyampaikan beberapa simpulan. Hasil evaluasi pelajaran matematika yang didapatkan siswa di siklus satu menunjukkan persentase siswa yang mencapai nilai $\geq 75$ baru mencapai 52,94\%. Pada siklus dua, dari hasil evaluasi dapat dilihat bahwa jumlah siswa yang telah mencapai $\geq$ 75 berjumlah $88,23 \%$. Hasil evaluasi siklus satu dari 92 siswa (52,94\%) menjadi 154 siswa atau 88,23\% pada siklus dua. Pada siklus dua ini jumlah siswa yang telah mencapai ketuntasan 154 siswa, atau $88,23 \%$. Hal ini berarti ketuntasan secara klasikal sudah berhasil karena batas ketuntasan yaitu $\geq 85 \%$.

\section{DAFTAR PUSTAKA}

Sani, A., Ridwan. Inovasi Pembelajaran. Jakarta: Bumi Aksara, 2013.

Sanjaya, Wina. Strategi Pembelajaran, Berorientasi Standar proses Pendidikan. Bandung, Prenada Media, 2013. Slameto. Belajar dan Faktor-faktor yang Mempengaruhinya. Jakarta: Rineka Cipta, 2010. 